«Keruen» scientific journal

M.O.Auezov Institute of Literature and Art

ISSN 2078-8134

Volume 2, Number 67 (2020)

https://doi.org/10.53871/2078-8134.2020.2-06

МРНТИ 17.07.29

\title{
К.Н. Жаппаркулова
}

Казахский национальный университет имени аль-Фараби

Казахстан, Алматы

e-mail: karlygash.zhapparkul@gmail.com

https://orcid.org/0000-0003-4238-4631

\section{Филологический анализ малой прозы Чингиза Айтматова}

Аннотация. Филологический анализ художественного текста опирается на литературоведческий и лингвистический подходы к произведению. Малая проза Ч. Айтматова, в которой прослеживаются истоки его мастерства и впервые отражены многие темы и мотивы, получившие дальнейшее развитие в жанре романа, не столь часто становилась предметом литературоведческого изучения. Проблемно-концептуальный анализ его рассказов и эссе ведет к постижению творческой индивидуальности писателя, своеобразия стиля и поэтики. В центре нашего литературоведческого исследования рассказы Ч. Айтматова, посвященные Великой Отечественной войне, одной из главных тем литературы XX века. Ведущей темой в них является любовь к Родине. Проблемы героического начала в типическом характере и внутренней нравственной силы главного героя наиболее сильно, образно и точно раскрыты в малой прозе Ч. Айтматова, для которой характерны глубокий психологизм, внимание к деталям и внутреннему миру персонажей.

В художественном тексте значим каждый его элемент. Для филологического анализа текста представляют особую важность жанр произведения, архитектоника, структура повествования и интертекстуальные связи.

Ключевые слова: национальная память, психологизм, проблемно-тематическое единство, интертекстуальные связи, архитектоника, художественность, поэтика, стиль, структура повествования.

Введение. Филологический анализ художественного текста синтезирует и обобщает лингвистические и литературоведческие подходы, методы и методику работы с конкретными произведениями писателя, поэта, драматурга. Поэтика, лингвистика текста, стилистика вовлечены в орбиту филологического анализа и детерминируют чтение и изучение произведения национальной литературы как процесс творческий, предполагающий множественность интерпретаций. Порой, читательское (и литературоведческое) восприятие прозы выходит из-под контроля художника. Каждый, кто прочитывает текст, создает свой образ личности писателя. Одна и та же вещь почти всегда может быть прочитана по-разному, причем не только разными читателями и исследователями, но и одним и тем же читателем и ученым-литературоведом.

Прозу Ч. Айтматова продолжают изучать представители разных литературоведческих направлений и научных школ. В данной статье мы предлагаем филологический анализ малой прозы Ч. Айтматова, стиля и поэтики.

Методы. Филологический анализ рассказов и эссе Ч. Айтматова проводится методом стилистической интерпретации, вскрывающей авторское отношение к описываемому. Полноценное эмоционально-художественное восприятие прозы 
неотрывно от знания быта, культуры народа. Методами исследования избраны историколитературный и сравнительно-типологический.

Результаты. В национальных литературах прошлое и его связь с настоящим переосмысливаются в разных ракурсах: традиции и новаторство, героическое и трагическое. Национальная память была для Ч. Айтматова важнейшей составляющей жизни родного кыргызского народа и литературного творчества, их постоянной константой. Национальная память неотделима от родного языка, а подлинное знание родной речи закладывается в детстве, поэтому так важен в ранней прозе кыргызского автора образ Учителя. Герои, действующие лица, персонажи его повествования живут, порой, в двух измерениях: в прошлом и настоящем. Большое значение имеет восприятие мира глазами ребенка.

Ценность человеческой жизни оставалась для Ч. Айтматова приоритетом в системе общечеловеческих и цивилизационных культурных традиций. Конструируя образ «чужого», автор-повествователь изучает его в социально-идеологической функции (защитник Отечества - враг, агрессор). Дискурс-анализ не отрицает реальность, виртуализируя ее и выдвигая на первый план «воображаемое». События в малой прозе Ч. Айтматова всегда выстроены в определенном ценностном ряду, истоки поступков - в детстве персонажей.

Филологический анализ избранных для исследования произведений малой формы позволяет раскрыть как ведущие тренды - преемственность исторического опыта и нравственную проблематику.

Обсуждение. По мнению современного исследователя, изучение военной прозы «составляет научную задачу, которая не теряет своей актуальности и представляет собой важный объект литературоведческих исследований» (Бурыкин, 2019: 523). В год юбилея Великой Победы мы вновь перечитываем произведения, посвященные подвигу защитников и тружеников тыла, переосмысливая с высоты современности богатейшее литературное наследие, посвящённое Великой Отечественной войне. Тема героизма, подвига, героические и трагические аспекты войны получили художественное воплощение в национальных литературах стран СНГ, в то время как «проблема соотношения парадигм национального и общечеловеческого является одной из вечных проблем во всех отраслях гуманитарных наук» (Матыжанов, 2019: 127).

Ч. Айтматов был убежден в том, что формирование и развитие в обществе исторической памяти невозможно без художественной литературы, без сохранения и передачи молодежи культурных ценностей, созданных человечеством. Как и академик Д.С. Лихачев, Ч. Айтматов был ярким представителем «сословия “людей мысли”, высоко это ценил» (Галашева, 2017: 252).

«Сложна и едва ли до конца постижима сама человеческая суть в её многомерных взаимоотношениях с окружающим миром. Есть личности, сумевшие в художественных символах и метафорах передать знаки Времени, исторические судьбы народа. Для Кыргызстана такой личностью явился Чингиз Айтматов, - убежден современный литературовед Бахтияр Койчуев. - Художественный мир Ч. Айтматова свидетельствует о том, что культурные пласты прошедших времён не исчезают бесследно, оставаясь в “долговременной” памяти народа, историко-культурном наследии, передающемся из поколения в поколение посредством слова, в котором запечатлеваются уходящие времена» (Койчуев, 2016: 46).

Стилевое пространство прозы Ч. Айтматова выстраивается вокруг неповторимого индивидуального стиля автора, который меняется, усложняется как от произведения к произведению, так и в рамках конкретного рассказа или эссе.

Для действующих лиц малой прозы Ч. Айтматова детство - особая пора. У многих персонажей рассказов, повестей, романов - детство, опаленное войной... Великая Отечественная война явилась, по мнению прозаика, «не только глобальной исторической вехой, разделившей XX век на две части - на довоенный и послевоенный периоды в 
развитии человечества, но и явилась судьбою, участью каждого человека, жившего в ту пору, мерилом его поступков и нравственных ценностей... Война предъявила максимальный счет каждому на его жизненном пути» (Айтматов, 1998: 35).

Филологический анализ текстов художественных произведений Ч. Айтматова подтверждает тот факт, что война разделила жизнь многих героев на «до» и «после»... Стала рубежом, позволила переосмыслить нравственные ценности. Военное прошлое главного героя Дюйшена в рассказе «Первый учитель» всплывает совершенно неожиданно, в реплике одного из присутствующих на открытии здания новой школы в аиле Куркуреу: «После войны вышел из госпиталя, на Украине это было, и остался там жить. Всего лет пять, как вернулся. Умирать, говорит, вернулся на родину. Всю жизнь бобылем так и живет» (Айтматов, 1998: 267). Многие из участников завершившейся торжественной церемонии вспоминают, что учились в школе Дюйшена, ему обязаны приобщением к знаниям. Немало его учеников погибло на войне, они были настоящими воинами.

Образ Учителя - знаковый для ранней прозы мастера художественного слова мирового уровня, а «выбор синтаксических конструкций дает широкие возможности стилизации, изменяющей временную перспективу текста» (Кострова, 2019: 155). Память о школьном учителе должна жить в аиле Куркуреу. Мотив памяти, особую роль которого раскрывает современный российский исследователь, «...как предикат, развертывая сообщение, “продвигает" речь в целом, так и мотив “продвигает" повествование, определяя перспективу событийного развития действия» (Силантьев, 2004: 79), становится ведущим для прозы Ч. Айтматова.

Малая проза Ч. Айтматова может быть лирической, психологической, философской, бытописательной. Но лейтмотив многих произведений - Великая победа. «Сколько горького счастья привалило народу: детвора бегала в школу с полевыми сумками отцов, к труду вернулись мужские руки, солдатки выплакали все глаза и молча примирились со своей вдовьей долей. А были такие, что все еще ждали своих близких. Ведь не все сразу вернулись домой» (Айтматов, 1998: 312).

Старик Чордон, главный герой рассказа Ч. Айтматова «Свидание с сыном», любуется широким простором холмистой долины, уходящей под самые снежные горы. На этой земле жил его сын, учитель, добровольцем ушедший на фронт.

Нравственная проблематика, воспитание подрастающего поколения, формирование духовных и моральных ценностей оставались для Ч. Айтматова главными на протяжении всего его творческого пути. И как напутствие звучат слова автора-повествователя, вложенные в уста Чордона, прощающегося с сыном перед отправкой эшелона на фронт: «Будь человеком, сын мой! Где бы ты ни был, будь человеком! Всегда оставайся человеком!» (Айтматов, 1998: 68).

Преемственность исторического опыта, национальная память передаются от поколения к поколению. Это непреложный закон жизни. Манкурты, не помнящие родства, беспамятные Сабитжаны - персонажи, не привлекательные ни для читателя, ни для автора. Нарратор стремится сохранить в своих художественных текстах «человеческое в человеке». С раннего детства научить различать добро, быть благодарными и внимательными к жителям родного аила, совхоза, города, всей страны. Прозаик, создавая текст, вступает в диалог с читателем, читателем реальным, т.е. биографическим лицом, погруженным в чтение текста. От читательского восприятия зависит и дальнейшая судьба художественного произведения, и стремление понять, как «слово, становясь образом, начинает воздействовать на природу человека» (Зинченко, Зусман, Кирнозе, 2017: 6).

Целыми днями бегал чумазый и счастливый пятилетний малыш, герой рассказа Ч. Айтматова «Солдатенок», среди стригалей, чабанов и лохматых пастушьих собак. С началом стригального сезона его мать, Джеенгуль, телефонистка почтового отделения, брала отпуск и подрабатывала подсобной работницей на стрижке овец. Солдатская вдова дорожила каждой копейкой. 
C мальчишеским восторгом смотрит фильм о войне маленький Авалбек. Кинопередвижка приехала во двор кошары. Вечером, как только стемнело, демонстрация картины началась: «На белом полотнище, повешенном между двумя столбами в конце кошары, началось сражение, загрохотали выстрелы, со свистом взмывали ввысь ракеты, добела освещая истерзанную всполохами тьму и приникших к земле разведчиков. Ракеты гасли, и разведчики снова бросались вперед. А пулеметы строчили среди ночи так, что у мальчика дух занимался. Вот это была война!» (Айтматов, 1998: 70).

Детское восприятие происходящего на экране («было ему не страшно, напротив, иногда даже очень весело, когда падали фашисты»; «Он умел падать и по-другому, как те, кому пуля попадала в живот») отличается от горестных комментариев зрительниц. Мать крепче прижимала его к себе. Но от романтичного восприятия фильма не остается и следа, когда мать, указывая на одного из артиллеристов, не похожего обличьем на русского, шепнула: «Смотри, это твой отец...».

С этой минуты весь фильм стал фильмом об отце. Меняется авторская оптика изображения и сам ракурс. Гамма самых радостных чувств переполняет душу мальчика. Несмышленыш «обрадовался, растерялся от этой неожиданной и незнакомой ему радости и по-детски возгордился своим отцом, солдатом» (Айтматов, 1998: 71). Отныне он не безотцовщина, а сын Токтосуна, который ушел на фронт молодым. И актер внешне был похож на молодого отца, запечатленного на военной фотографии, на молодого солдата в пилотке.

Поменялось отношение ребенка к войне, который смотрел на отца глазами сына. Война из забавной стала серьезной, тревожной, страшной. Горячая волна неизведанной сыновней любви и нежности поднималась в детской душе. Новый ассоциативный ряд выстраивает Ч. Айтматов: «Отец на экране словно бы знал, что за ним следит сын, и словно бы хотел за свою мгновенную жизнь в кино показать себя таким, чтобы сын вечно помнил о нем и вечно гордился им - солдатом минувшей войны... Он впервые испытал чувство страха за близкого человека, за того человека, которого ему всегда не хватало» (Айтматов, 1998: 73).

Ребенок реагирует на происходящее на экране так, как будто «он рядом с отцом, в огне и грохоте войны». Он подпрыгивает на коленях у матери, притихает, собирается в комок, когда падают солдаты... Видя подвиг отца на экране, он готов броситься к нему, еще живому, медленно встающему с земли, идущему навстречу танку. Отец «обгоревший, в дымящихся клочьях одежды» собирает в себе последние силы и замахивается гранатой.

Сам писатель в эссе и очерках нередко вспоминал о своем детстве, о сверстниках военных лет, которые стали уважаемыми людьми. «Наш тихий Шекер у подножия вечного Манаса, находясь среди гор, вдруг оказался в быстрине общих событий, потрясающих мир. Наши люди, призванные на защиту Отечества, хлынули на фронты, к нам докатывались волны эвакуированных... Одним из первых, кто рассказал нам о войне, о фронте, о схватках с танками, о бомбовых разрывах, о лесных пожарах, о человеке и сражениях, о госпиталях, о военных хирургах, о смерти и мужестве, был наш знаменитый аильный певец поэт Мырзабай Укуев» (Айтматов, 1998: 50).

Уже в первых своих произведениях Ч. Айтматов мастерски выстраивает композицию и структуру повествования, опираясь на интертекстуальные связи. Н.А. Кузьмина предлагает в соотношение «произведение - текст» ввести временной фактор. Пока автор работает над произведением, он имеет дело с текстом. «Момент, когда работа завершена, есть момент рождения произведения как законченного целого. Однако уже следующий момент знаменует отторжение произведения от автора и превращение его в текст» (Кузьмина, 2007: 24).

В перерыве кинопоказа, когда киномеханик после первой части фильма включил свет, чтобы перезарядить ленту, солдатенок бежал к экрану, к сидевшим в первых рядах друзьям с радостной вестью, что это был его отец. 
Психологически точно автор рассказа передает реакцию зрителей. Это и странная, неловкая тишина, и растерянное молчание, и пожимание плечами... Реакция киномеханика передана настолько верно, что словно слышен звук выроненной им коробки от киноленты, звякнувшей и покатившейся, разлетевшейся на две половинки. «Но никто не обратил внимания, и сам киномеханик не бросился поднимать». При помощи «образной метафоры человек может кратко, емко, но в то же время ярко выразить свое душевное состояние и охарактеризовать другого человека» (Сансызбаева, Спанбек, Темиркулова, 2019: 146).

Взрослые не хотят лишать Авалбека его горькой и прекрасной иллюзии. Дети первые говорят правду малышу: «Да это не твой отец... Вовсе не твой отец, а артист» (Айтматов, 1998: 75).

Именно «с этого часа в нем начал жить отец, давно погибший на войне». Скорбная и строгая, в слезах мама малыша по-прежнему непоколебима: «Это был твой отец». Новая гамма чувств охватила мальчика: обидно, горестно, больно. Но он молчал, сжав кулаки и сглатывая слезы. Вечерний пейзаж подчеркивает его безутешное горе: «Луна стояла уже высоко. В темно-синей ночной дали белели горные вершины, а степь внизу лежала громадная и непроглядная как омут» (Айтматов, 1989: 76). Детство самого писателя «было осирочено в горниле революции и становления советской власти, отрочество опалено в пламени Великой Отечественной войны. Он выстоял, закалился и зашагал в ногу с эпохой, а во многом и опережая её, чувствуя времена перемен» (Койчуев, 2016: 46).

Тема настоящего, не показного героизма, любви к Родине - ведущая в романе Ч. Айтматова «И дольше века длится день», повествовании многоплановом, романное время которого объемно и растяжимо. Трагически гибнет один из героев романа бывший школьный учитель и фронтовик - партизан Абуталип Куттыбаев.

По праву памяти, творческое наследие выдающегося мастера художественного слова Ч. Айтматова останется в мировой литературе, поскольку к проблемам планетарного масштаба он выходил через национальное миросозерцание, говоря о проблемам вечных, общечеловеческих. Филологический анализ прозы и публицистики Ч. Айтматова обогатит мировое литературоведение новыми акцентами в анализе стиля и поэтики, новым прочтением малой прозы писателя.

\author{
К.Н. Жаппаркұлова \\ Әл-Фараби атындағы Қазақ ұлттық университеті \\ Қазақстан, Алматы \\ e-mail: karlygash.zhapparkul@gmail.com
}

\title{
Шыңғыс Айтматовтың кіші прозасының филологиялық талдауы
}

Аңдатпа. Көркем мәтінді филологиялық талдау шығарманың әдеби және лингвистикалық тәсілдеріне сүйенеді. Ш. Айтматовтың кіші прозасында оның шеберлігінің қайнар көзі және роман жанрында одан әрі даму алған көптеген тақырыптар мен уәждер алғаш рет көрсетілген. Оның әңгімелері мен эсселеріне проблемалықтұжырымдамалық талдау жазушының шығармашылық даралығын, стиль мен поэтиканың өзіндік ерекшелігін ұғынуға әкеледі. Біздің әдебиеттанулық зерттеу орталығында XX ғасыр әдебиетінің басты тақырыптарының бірі Ұлы Отан соғысына арналған Ш. Айтматовтың әңгімелері. Жетекші тақырып, оларға Отанға деген сүйіспеншілік болып табылады. Басты кейіпкердің тән сипаты мен ішкі адамгершілік күші батырлық бастаудың мәселелері Ш. Айтматовтың кіші прозасында өте, бейнелі және дәл ашылған, оған терең психологизм, кейіпкерлердің егжей-тегжейі мен ішкі әлеміне назар аударылады.

Көркем мәтінде оның әрбір элементі маңызды. Мәтінді филологиялық талдау үшін шығарманың жанры, сәулет өнері, әңгіме құрылымы және интертекстуалды байланыс ерекше маңызды. 
Кілттік сөздер: ұлттық жады, психологизм, проблемалық-тақырыптық бірлік, интертекстуалды байланыс, сәулет өнері, көркемдік, поэтика, стиль, баяндау құрылымы.

\author{
K.N.Zhapparkulova \\ Al-Farabi Kazakh National University \\ Kazakhstan, Almaty \\ e-mail: karlygash.zhapparkul@gmail.com
}

\title{
Philological analysis of flash fiction by Chingiz Aitmatov
}

\begin{abstract}
The philological analysis of a literary text is based on literary and linguistic investigations. Any element of the philological analysis is significant in a literary text. Though a lesser researched area of his work, the flash fiction of Chingiz Aitmatov for the first time reflected many themes and motives that were further developed in the genre of the novel. The problem-conceptual analysis of his stories and essays, the originality of style and poetics - lead to the comprehension of the creative personality of the writer. At the center of our literary research are the stories Aitmatov devoted to the Great Patriotic War, one of the main topics of literature of the twentieth century. The leading theme in them is the love of the motherland. The problems of the heroic principle in the typical character, the internal moral strength of the hero are most strongly, figuratively and accurately revealed in the flash fiction of Aitmatov, which is characterized by deep psychologism, attention to details and the inner world of the characters.

For the philological analysis of the text, the genre of the work, architectonics, narrative structure and intertextual relations are of particular importance.

Keywords: national memory, psychologism, spiritual origins, intertextual communications, architectonics, artistry, poetics, style, narrative structure

\section{Сведения об авторе}

Жаппаркулова Карлыгаш - докторант PhD II курса Казахского национального университета имени аль-Фараби (Алматы, Республика Казахстан), ORCID iD: https://orcid.org/0000-0003-4238-4631, Scopus iD: 57211035566
\end{abstract}

\section{ЛИТЕРАТУРА}

[1] Айтматов Ч. (1998). Первый учитель (259-318). Собрание сочинений в семи томах. Т. 1. Рассказы. Повести. Москва, Россия (рус.).

[2] Айтматов Ч. (1998). Свидание с сыном (53-68). Собрание сочинений в семи томах. Т. 6. Рассказы. Плач охотника над пропастью (Исповедь на исходе века). Диалоги. Москва, Россия (рус.).

[3] Айтматов Ч. (1998). Солдатенок (69-76). Собрание сочинений в семи томах. Т. 6. Рассказы. Плач охотника над пропастью (Исповедь на исходе века). Диалоги. Москва, Россия (рус.).

[4] Айтматов Ч. (1998). Снега на Манас ата (33-55). Собрание сочинений в семи томах. Т. 7. Статьи. Выступления. Эссе. Диалоги. Москва, Россия (рус.).

[5] Бурыкин А.А. (2019). Феномен лейтенантской прозы и проза М. Ханинова о войне. Национальная литература России в поликультурном пространстве: духовно-нравственный и консолидирующий потенциал (523-538). Элиста, Россия: КалмНЦ РАН (рус.).

[6] Галашева T.H. (2017). Пятые Лихачевские чтения. Русская литература (WoS), 4, 252-259 (рус.).

[7] Зинченко В.Г., Зусман В.Г., Кирнозе З.И. (2017). Литература и методы ее изучения. Системносинергетический подход. Москва: Флинта, Наука (рус.).

[8] Койчуев Б. (2016). Литература Кыргызстана (46-66). Мировой литературный процесс XXI века. Алматы, Казахстан: Әдебиет Әлемі (рус.).

[9] Кострова О.А. (2019). Современный немецкий роман в свете лингвориторики. Лингвориторическая парадигма: теоретические и прикладные аспекты (РИНЦ). 24, 152-155 (рус.).

[10] Кузьмина Н.А. (2007). Интертекст и его роль в процессах эволюции поэтического языка. Москва: КомКнига (pyc.).

[11] Матыжанов К.С. (2019). Межлитературные взаимодействия: актуальность и перспективность. Национальные литературы на современном этапе: научные концепции и гипотезы (123-128). Казань: ИЯЛИ (рус.).

[12] Сансызбаева С.К., Спанбек А.Н., Темиркулова Г.К. (2019). Зооморфизмы в языковой картине мира (на материале описания концептов «мужчина» и «женщина» в русском и казахском языках). Вестник КазНУ имени альФараби. 3 (175), 146-152 (рус.).

[13] Силантьев И.В. (2004). Поэтика мотива. Москва: Языки славянской культуры (рус.).

[14] Tattimbetova K., Ananyeva S., Zhaksylykov A. (2016). The author's self-reflection in narratology of I.P. Shegolikhin. Journal of Language and Literature (Scopus), Vol. 7, 3, 26-32 (англ.). 


\section{ӘДЕБИЕТ}

[1] Айтматов Ч. (1998). Бірінші мұғалім (259-318). Жеті томдық шығармалар жинағы. Т. 1. Әңгімелер. Повестері. Мәскеу, Ресей (орыс.).

[2] Айтматов Ч. (1998). Ұлмен кездесу (53-68). Жеті томдық шығармалар жинағы. Т. 6. Әңгімелер. Аңшының зары над пропастью (Исповедь, қарсыластар ғасыр). Диалогтар. Мәскеу, Ресей (орыс.).

[3] Айтматов Ч. (1998). Солдатенка (69-76). Жеті томдық шығармалар жинағы. Т. 6. Әңгімелер. Аңшының зары над пропастью (Исповедь, қарсыластар ғасыр). Диалогтар. Мәскеу, Ресей (орыс.).

[4] Айтматов Ч. (1998). Қар Манас ата (33-55). Жеті томдық шығармалар жинағы. Т. 7. Мақалалар. Сөз сөйлеулер. Эссе. Диалогтар. Мәскеу, Ресей (орыс.).

[5] Бурыкин А. А. (2019). Лейтенант прозасының феномені және М. Ханиновтың соғыс туралы прозасы. Көпмәдени кеңістіктегі Ресейдің ұлттық әдебиеті: рухани-адамгершілік және біріктіруші әлеует (523-538). Элиста, Ресей: КалмНЦ PAH (орыс.).

[6] Галашева Т. Н. (2017). Бесінші Лихачев оқулары. Орыс әдебиеті( WoS), 4, 252-259 (орыс.).

[7] Зинченко В. Г., Зусман В. Г., З. И. Кирнозе (2017). Әдебиет және оны зерттеу әдістері. Жүйелік-синергетикалық тәсіл. Мәскеу: Флинт, ғылым (орыс.).

[8] Койчуев. Б. (2016). Қырғыз Әдебиеті (46-66). ХХІ ғасырдағы әлемдік әдеби процесс. Алматы, Қазақстан: Әдебиет Әлемі (орыс.).

[9] Кострова О. А. (2019). Қазіргі неміс романы лингвориторика. Лингвистикалық парадигма: теориялық және қолданбалы аспектілер (РИНЦ). 24, 152-155 (орыс.).

[10] Кузьмина Н.А. (2007). Интертекст және оның поэтикалық тілдің эволюциясындағы рөлі. Мәскеу: КомКнига (орыс.).

[11] Матыжанов К. С. (2019). Пәнаралық өзара іс-қимыл: өзектілігі және болашағы. Қазіргі кезеңдегі ұлттық әдебиеттер: ғылыми концепциялар мен гипотезалар (123-128). Қазан: ИЯЛИ рус.).

[12] С. К. Сансызбаева, А. Н. Спанбек, Г. К. Темірқұлова (2019). Әлемнің тілдік көрінісіндегі зооморфизмдер ("мужчина" және "женщина" концептілерін сипаттау материалында орыс және қазақ тілдерінде). Әл-Фараби атындағы ҚазҰУ хабаршысы. 3 (175), 146-152 (орыс.).

[13] И. В. Силантьев (2004). Поэтика мотива. Мәскеу: славян мәдениеті тілдері (орыс.).

[14] Тәттімбетова Қ. Ананьева С., Жақсылықов А. (2016). И. П. Щеголихин нарратологиясындағы автор авторефлексиясы. Тіл және әдебиет журналы (Скопус), Том 7, 3, 26-32 (ағыл.).

\section{REFERENCES}

[1] Aitmatov Ch. (1998). The first teacher (259-318) Collected works in seven volumes. T. 1. Stories. Novels. Moscow, Russia (rus.).

[2] Aitmatov Ch. (1998). Appontment with son (53-68). Collected works in seven volumes. T. 6. Stories. Hunter's cry above the steep (Confession at the End of the Century). Dialogs. Moscow, Russia (rus.).

[3] Aitmatov Ch. (1998). Soldier boy (69-76). Collected works in seven volumes. T. 1. 6. Stories. Hunter's cry above the steep (Confession at the End of the Century). Dialogs. Moscow, Russia (rus.).

[4] Aitmatov Ch. (1998). Snow on Manas-Ata (33-55). Collected works in seven volumes. T. 7. Articles. Speeches. Essays. Dialogs. Moscow, Russia (rus.).

[5] Burykin A.A. (2019). The phenomenon of lieutenant prose and the prose of M. Haninov about the war. Russian national literature in a multicultural space: spiritual, moral and consolidating potential (523-538).Elista, Russia: Kalmyk NC RAS (rus.).

[6] Galasheva T.N. (2017). The Fifth Lichachyov's readings. Russian literature (WoS), 4, 252-259 (rus.).

[7] Zinchenko V.G., Sussman V.G., Kirnose Z.I. (2017). Literature and methods of its study. Systemic synergistic approach. Moscow: Flint, Science (rus.).

[8] Koychuev B. (2016). Literature of Kirgizstan (46-66). The world literary process of the 21st century. Almaty, Kazakhstan: Adebiet Alemy (rus.).

[9] Kostrova O.A. (2019). A modern German novel in the light of linguistic rhetoric. Linguistic paradigm: theoretical and applied aspects (RISC). 24, 152-155 (rus.).

[10] Kuzmina N.A. (2007). Intertext and its role in the processes of evolution of poetic language. Moscow: KomKniga (rus).

[11] Matyzhanov K.S. (2019). Inter-literary interactions: relevance and prospects. National Literature at the Present Stage: Scientific Concepts and Hypotheses (123-128). Kazan: ILLA (rus.).

[12] Sansyzbaeva S.K., Spanbek A.N., Temirkulova G.K. (2019). Zoomorphisms in the linguistic picture of the world (based on the description of the concepts «man» and «woman» in Russian and Kazakh languages).VESTNIK of KazNU after Al-Farabi. 3 (175), 146-152 (rus.).

[13] Silantyev I.V. (2004). The poetics of motive. Moscow: Languages of Slavic culture (rus.).

[14] Tattimbetova K., Ananyeva S., Zhaksylykov A. (2016). The author's self-reflection in narratology of I.P. Shegolikhin. Journal of Language and Literature (Scopus), Vol. 7, 3, 26-32 (eng.). 